\title{
PENGARUH KUALITAS PRODUK DAN LAYANAN TERHADAP KEPUTUSAN PEMBELIAN PRODUK TABUNGAN PADA BANK SYARIAH MANDIRI CABANG BOGOR
}

\author{
Gani Wiharso $^{1}$, Mohammad Benny Alexandri \\ ${ }^{1}$ Sekolah Tinggi Ekonomi Indonesia \\ ${ }^{2}$ Universitas Padjadjaran \\ gwiharso_16@yahoo.com¹, bennyalexandri@yahoo.co.id²
}

\begin{abstract}
ABSTRAK
Abstrak - Penelitian ini bertujuan untuk mengetahui pengaruh kualitas produk dan layanan terhadap keputusan pembelian produk tabungan pada PT. Bank Syariah Mandiri cabang Bogor. Metode yang digunakan yaitu metode survey dengan menggunakan teknik analisis deskriftif dan verifikatif. Teknik pengambilan sampel penelitian ini menggunakan teknik purposive sampling sebanyak 86 responden. Teknik pengumpulan data menggunakan kuesioner sebanyak 30 item pertanyaan yang dinilai dengan skala Likert 1-5 dan diuji validitas serta reliabilitasnya. Pengujian hipotesis menggunakan analisis statistik meliputi koefisien korelasi, koefisien determinasi, uji-t, dan uji F. Berdasarkan hasil pengujian parsial dapat disampaikan sebagai berikut : (1) Pengaruh kualitas produk $\left(\mathrm{X}_{1}\right)$ terhadap keputusan pembelian produk diperoleh nilai $t_{\text {hitung }}$ lebih besar dari nilai $t_{\text {tabel, }}$, yaitu 4,917 > 2,025 (nilai koefisien regresi 0,572 dan nilai signifikansi 0.000), maka $\mathrm{H}_{0}$ ditolak dan $\mathrm{H}_{\mathrm{a}}$ diterima. Sehingga dapat disimpulkan bahwa variabel kualitas produk secara parsial mempunyai pengaruh positif dan signifikan terhadap terhadap keputusan pembelian produk. (2) Pengaruh kualitas layanan $\left(\mathrm{X}_{2}\right)$ terhadap keputusan pembelian produk diperoleh nilai $\mathrm{t}_{\text {hitung }}$ lebih besar dari nilai $t_{\text {tabel, }}$ yaitu 2,675> 2,025 (nilai koefisien regresi 0,324 dan nilai signifikansi 0.009), maka $\mathrm{H}_{0}$ ditolak dan $\mathrm{H}_{\mathrm{a}}$ diterima. Sehingga dapat disimpulkan bahwa variabel kualitas layanan mempunyai pengaruh positif dan signifikan terhadap keputusan pembelian produk. (3) Pengaruh kualitas produk $\left(\mathrm{X}_{1}\right)$ dan kualitas layanan $\left(X_{2}\right)$ terhadap keputusan pembelian produk diperoleh $F_{\text {hitung }}=49,573>F$ tabel 3,109 maka $\mathrm{H}_{0}$ ditolak dan $\mathrm{H}_{\mathrm{a}}$ diterima, sehingga dapat disimpulkan pengaruh kualitas produk dan kualitas layanan secara simultan berpengaruh secara signifikan terhadap keputusan pembelian produk. Hasil analisis koefisien determinasi dengan nilai adjusted R Square sebesar 0,550 maka dapat diartikan bahwa 50,5\% kualitas produk dan layanan berpengaruh terhadap keputusan pembelian produk tabungan pada Bank Syariah Mandiri cabang Bogor.
\end{abstract}

Kata kunci: Kualitas Produk, Layanan, dan Keputusan Pembelian Produk Tabungan

\begin{abstract}
This study aims to determine the effect of product and service quality on purchasing decisions on savings products at PT. Bank Syariah Mandiri Bogor branch. The method used is a survey method using descriptive analysis techniques and verification. The sampling technique of this study used a purposive sampling technique of 86 respondents. Data collection techniques used a questionnaire of 30 question items which were assessed with a Likert scale of 1-5 and tested for validity and reliability. Hypothesis testing using statistical analysis includes correlation coefficient, coefficient of determination, t-test, and F test. Based on the results of partial testing can be conveyed as follows: (1) The effect of product quality (X1) on product purchasing decisions obtained tcount value greater than ttable, ie 4.917> 2.025 (regression coefficient 0.572 and significance value 0.000), then $\mathrm{HO}$ is rejected and Ha is accepted. So it can be concluded that the product quality variable partially has a positive and significant influence on product purchasing decisions. (2) The effect of service quality (X2) on product purchase decisions obtained tcount greater than
\end{abstract}


ttable, ie 2.675> 2.025 (regression coefficient value 0.324 and significance value 0.009), then HO is rejected and Ha is accepted. So it can be concluded that the service quality variable has a positive and significant influence on product purchasing decisions. (3) Effect of product quality (X1) and service quality (X2) on product purchasing decisions obtained Fcount $=49.573>$ F table 3.109 then HO is rejected and $\mathrm{Ha}$ is accepted, so it can be concluded that the influence of product quality and service quality simultaneously significantly influences the decision product purchase. The results of the analysis of the coefficient of determination with an adjusted $R$ Square value of 0.550 can be interpreted that $50.5 \%$ of the quality of products and services influence the decision to purchase savings products at the Bogor branch of Syariah Bank Mandiri.

Keywords: Product Quality, Service, and Savings Product Purchasing Decisions

\section{Pendahuluan}

Bank merupakan lembaga yang pada dasarnya melakukan penghimpunan dana dari masyarakat dan menyalurkannya kepada masyarakat dalam bentuk kredit/pembiayaan dalam rangka meningkatkan taraf hidup masyarakat atau dengan kata lain melaksanakan fungsi intermediasi keuangan.

Perbankan dengan system syariah baru muncul di Indonesia pada tahun 1991, dan merupakan hal baru dalam sistem perbankan nasional yaitu pada saat pendirian PT Bank Muamalat Indonesia (BMI) pada tanggal 1 Nopember 1991. Berdirinya BMI tidak langsung diikuti oleh pendirian Bank-bank Syariah lainnya, sehingga perkembangan perbankan syariah relative stagnan sampai tahun 1998.

Dengan adanya krisis ekonomi dan krisis moneter yang melanda Indonesia pada tahun 1998 serta keluarnya Undang-undang Nomor 10 Tahun 1998 tentang perubahan atas Undang-undang Nomor 7 Tahun 1992 tentang perbankan, dimana isinya mengatur tentang peluang usaha syariah bagi Bank konvensional . Maka berdirilah Bank syariah berikutnya yaitu Bank Syariah Mandiri yang berdiri tanggal 1 Nopember 1999 dan beberapa Unit Usaha Syariah (UUS) seperti Bank BNI pada tahun 2000, UUS Bank BRI, dan UUS beberapa Bank Swasta.

Perkembangan jumlah Bank Umum Syariah dan Unit Usaha Syariah di Indonesia sejak tahun 2003 sampai dengan tahun 2017 dapat dilihat pada gambar dibawah ini.

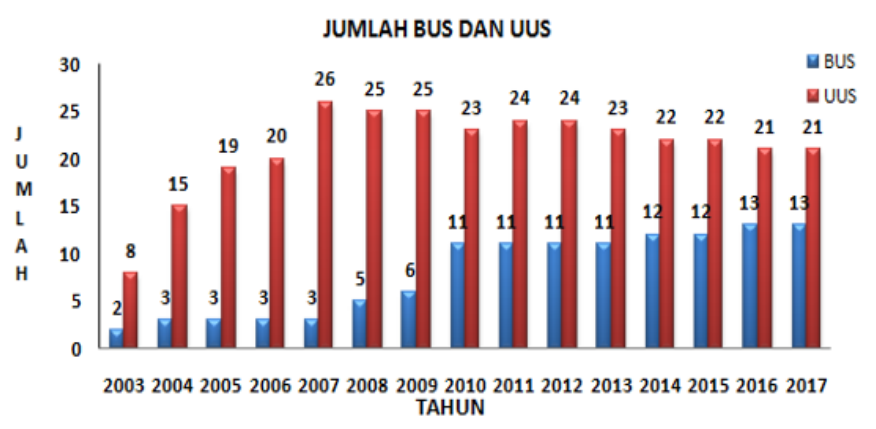

Tingkat persaingan antar bank cukup ketat, karena semua bank berusaha dalam meraih pasar dan mendapatkan nasabah dengan cara menawarkan produk-produk yang dimilikinya. Sesuai kebutuhan dan fasilitas yang ditawarkan, nasabah akan memilih dari produk beberapa bank tersebut. Dengan semakin banyaknya bank-bank syariah, maka semakin banyak pula pilihan bagi nasabah untuk dapat memilih produk yang sesuai dengan apa yang menjadi harapannya. Dan akibatnya, nasabah menjadi lebih cermat dan pintar dalam memilih setiap produk yang ada dalam setiap penawaran yang disampaikan oleh bank. Disinilah keberadaan Bank BSM mulai diuji, dengan semakin banyaknya bank syariah yang ada, yang mana saling berlomba-lomba untuk memberikan yang terbaik kepada para calon nasabah ataupun para nasabahnya.

Kualitas pelayanan mempunyai peranan yang penting bagi bisnis jasa perbankan dalam upaya merebut nasabah di pasar. Dengan banyaknya bank yang berdiri baik bank konvensional maupun bank syariah, maka setiap bank harus terus berupaya meningkatkan kualitas layanan agar para nasabah loyal menggunakan jasa perbankan yang ditawarkannya. 
Kemampuan untuk memberikan kepuasan pada pemakainya akan menguatkan kedudukan atau posisi produk dalam benak nasabah, sehingga memungkinkan nasabah menjadikan pilihan pertama ketika mendaftarkan diri menjadi nasabah Bank BSM. Jadi, dalam usaha jasa bahwa kepuasan nasabah adalah menjadi salah satu yang diutamakan tidak terkecuali di Bank BSM, karena hal itulah yang akan menentukan berhasil atau gagalnya suatu usaha jasa seperti Bank BSM. Nasabah yang merasa tidak puas tentu tidak akan mengulangi lagi memilih jasa yang sama, apalagi didukung dengan adanya pilihan jasa perbankan syariah yang lain, sehingga membuat para nasabah memiliki banyak perbandingan untuk memutuskan pilihan di Bank mana yang diinginkannya.

Keputusan menabung nasabah merupakan proses pengenalan kebutuhan nasabah yang dipicu rangsangan internal terhadap informasi sebuah produk. Keputusan menabung nasabah diukur berdasarkan indikator : konsumen menyadari suatu masalah atau kebutuhan yang di cari, konsumen mencari informasi lebih lanjut, konsumen melakukan evaluasi sebelum memutuskan membeli, konsumen memutuskan untuk membeli produk yang dibutuhkan atau diinginkan, konsumen merasa puas.

Berdasarkan uraian di atas, maka dapat di buat rumusan permasalahan yaitu sebagai berikut:

1. Apakah kualitas produk tabungan berpengaruh terhadap keputusan pembelian produk tabungan di PT. Bank Syariah Mandiri cabang Bogor?

2. Apakah kualitas layanan berpengaruh terhadap keputusan pembelian produk tabungan di PT. Bank Syariah Mandiri cabang Bogor?

3. Apakah kualitas produk tabungan dan kualitas layanan berpengaruh secara simultan terhadap keputusan pembelian produk tabungan di PT. Bank Syariah Mandiri cabang Bogor

\section{KAJIAN PUSTAKA}

\section{A. Kualitas Produk}

Menurut pendapat Kotler dan Armstrong (2008) kualitas adalah karakteristik dari produk dalam kemampuan untuk memenuhi kebutuhan-kebutuhan yang telah ditentukan dan bersifat laten.

Menurut Tjiptono dan Anastasia Diana (2016:143), kualitas adalah totalitas fitur dan karakteristik produk atau jasa yang bergantung pada kemampuannya untuk memuaskan kebutuhan yang dinyatakan atau tersirat.

Menurut Kotler and Armstrong (2008) arti dari kualitas produk adalah kemampuan sebuah produk dalam memperagakan fungsinya, hal itu termasuk keseluruhan durabilitas, reliabilitas, ketepatan, kemudahan pengoperasian dan reparasi produk juga atribut produk lainnya.

\section{B. Pelayanan}

Menurut Tjiptono (2012:4) pelayanan (service) bisa dipandang sebagai sebuah sistem yang terdiri atas dua komponen utama, yakni service operations yang kerap kali tidak tampak atau tidak diketahui keberadaannya oleh pelanggan (back office atau backstage) dan service delivery yang biasanya tampak (visible) atau diketahui pelanggan (sering disebut pula front office atau frontstage).

Pelayanan dalam hal ini sangat erat kaitannya dengan hal pemberian kepuasaan terhadap pelanggan, pelayanan dengan mutu yang baik dapat memberikan kepuasaan yang baik pula bagi pelanggannya, sehingga pelanggan dapat lebih merasa diperhatikan akan keberadaanya oleh pihak perusahaan.

Menurut Fandy Tjiptono dan Gregorius Chandra (2017:204), di dalam mengevaluasi kualitas pelayanan perusahaan yang dapat digunakan sebagai kerangka perencanaan strategi dan analisis, adapun dimensi-dimensi tersebut adalah sebagai berikut:

a. Bukti langsung (tangibles), segala fasilitas fisik termasuk perlengkapan yang nampak dimata konsumen. Seperti lokasi, kebersihan ruangan, tempat parkir, keterampilan pegawai dan sarana komunikasi.

b. Empati (empathy), meliputi kemudahan dalam melakukan hubungan komunikasi yang baik, perhatian pribadi dan memahami kebutuhan para konsumen.

c. Kehandalan (reliability), yakni kemampuan memberikan pelayanan sesuai yang di janjikan terpercaya dan akurat, konsisten dan sesuai pelayanan.

d. Daya tanggap (responsiveness), yaitu keinginan dari para staf dan karyawan untuk membantu para pelanggan dan memberikan pelayanan dengan cepat.

e. Jaminan (assurance), mencakup pengetahuan, kemampuan kesopanan dan sifat dapat dipercaya yang dimiliki para staf, bebas dari bahaya, risiko atau keragu-raguan. 


\section{Keputusan Pembelian}

Menurut Kotler (2014), "Keputusan pembelian adalah Suatu tahap dimana konsumen telah memiliki pilihan dan siap untuk melakukan pembelian atau pertukaran antara uang dan janji untuk membayar dengan hak kepemilikan atau penggunaan suatu barang atau jasa”.

Menurut Peter Jerry C. Olson (2013) Keputusan pembelian adalah suatu keputusan (decision) mencakup suatu pilihan diantara dua atau lebih tindakan atau perilaku alternatif.

Ada tujuh komponen dalam keputusan pembelian yang diputuskan yaitu :

\section{a. Keputusan tentang jenis produk}

Dalam hal ini konsumen dapat mengambil keputusan tentang produk apa yang akan dibelinya untuk memenuhi dan memuaskan kebutuhan.

\section{b. Keputusan tentang bentuk produk}

Konsumen dapat mengambil keputusan untuk membeli suatu produk dengan bentuk tertentu sesuai dengan seleranya.

c. Keputusan tentang merek

Konsumen harus mengambil keputusan tentang merek mana yang akan dibeli karena setiap merek mempunyai perbedaan-perbedaan tersendiri.

\section{d. Keputusan tentang penjualnya}

Konsumen dapat mengambil keputusan dimana produk yang dibutuhkan tersebut akan dibeli.

e. Keputusan tentang jumlah produk

Konsumen dapat mengambil keputusan tentang seberapa banyak produk yang akan dibeli.

\section{f. Keputusan tentang waktu pembelian}

Konsumen dapat mengambil keputusan tentang kapan dia harus melakukan pembelian.

\section{g. Keputusan tentang cara pembayaran}

Konsumen dapat mengambil keputusan tentang metode atau cara pembelian produk yang akan dibeli, apakah secara tunai atau kredit. Keputusan tersebut akan mempengaruhi keputusan tentang penjualan dan jumlah pembeliannya.

Berdasarkan penjelasan maka dapat dibuat kerangka pemikiran teoritis sebagai berikut :

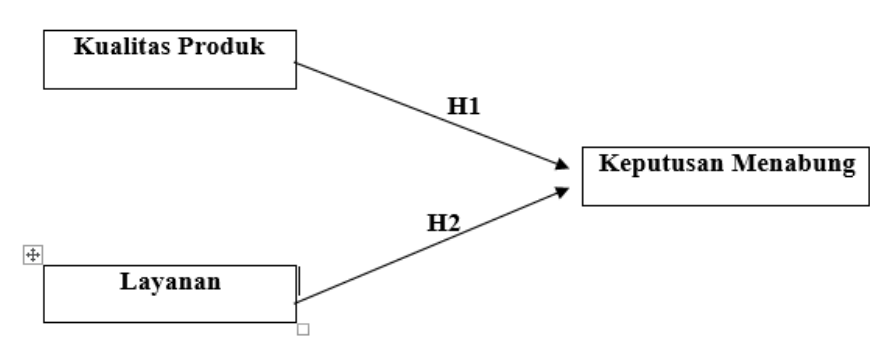

Hipotesis

H1 : Terdapat pengaruh yang signifikan dari kualitas produk yang ditawarkan terhadap keputusan menabung.

H2 : Terdapat pengaruh yang signifikan dari layanan terhadap keputusan menabung.

H3 : Terdapat pengaruh yang signifikan dari kualitas produk dan layanan terhadap keputusan menabung.

\section{METODE PENELITIAN}

Teknik pengambilan sampel dalam penelitian ini yaitu non probability sampling yaitu tipe purposive sampling. Purposive sampling adalah cara pengambilan sampel berdasarkan pertimbangan tertentu. Dalam penelitian ini yang dijadikan sampel adalah nasabah atau pengunjung yang sering melakukan transaksi di PT. Bank Syariah Mandiri Cabang Bogor, alasan pertimbangan ini dikarenakan penulis memiliki pandangan bahwa nasabah tersebut lebih memiliki alasan kuat dalam memberikan informasi yang lebih baik terhadap penelitian ini.

Untuk menentukan besarnya sampel, penulis menggunakan rumus Slovin dengan tingkat kesalahan $10 \%$, sehingga tingkat kewajaran terjadinya kesalahan dalam pengambilan sampel masih dapat ditolerir dalam penelitian ini. Berdasarkan perhitungan maka jumlah sampel yang digunakan dalam penelitian ini sebanyak 86 orang.

Teknik analisis data yang digunakan dalam penelitian pengaruh antara variabel Produk dan Layanan terhadap variabel Keputusan Pembelian Produk Tabungan adalah kombinasi antara teknik statistik deskriptif dan teknik statistik inferensial:

1. Teknik statistik deskriptif, dalam hal ini digunakan untuk menyajikan data setiap variabel secara sendiri-sendiri dan selanjutnya juga digunakan untuk mengukur gejala pusat yang mencakup median, modus, rerata dan ukuran penyebaran dengan menggunakan standar deviasi serta dilengkapi dengan tabel frekwensi dan grafik berbentuk histogram. 
2. Teknik statistik inferensial, dipergunakan untuk menguji hipotesis penelitian, dengan analisis regresi dan korelasi sederhana/berganda dan sebelumnya dilakukan pengujian terhadap persyaratan analisis melalui uji taksiran untuk setiap regresi sederhana maupun berganda serta uji homogenitas varian $\mathrm{Y}$ atas variabel $\mathrm{X}_{1}, \mathrm{X}_{2}$, dan Y.

Dalam penelitian ini, ada dua variabel bebas dan satu variabel terikat. Dengan demikian, regresi linier berganda dinyatakan dalam persamaan matematika sebagai berikut:

$$
\mathrm{Y}=\mathrm{a}+\mathrm{b} 1 \mathrm{X} 1+\mathrm{b} 2 \mathrm{X} 2+\mathrm{e}
$$

Keterangan:

$\begin{array}{rll}\text { Y : } & \text { Variabel Terikat (Keputusan } \\ \text { Menabung) } & \\ \text { X1 : } & \text { Variabel Bebas (Produk) } \\ \text { X2 : } & \text { Variabel Bebas (Layanan) } \\ \text { a : } & \text { Konstanta } \\ \text { b : } & \text { Koefisien garis regresi } \\ \text { e : } & \text { error /variabel pengganggu }\end{array}$

\section{PEMBAHASAN}

Berdasarkan hasil analisis regresi berganda, maka dapat diperoleh suatu persamaan garis regresi sebagai berikut :

$$
\hat{\mathbf{Y}}=3,224+0,572 \mathrm{X} 1+0,324 \mathrm{X} 2+\mathrm{e}
$$

Berdasarkan persamaan di atas, maka dapat diinterpretasikan sebagai berikut :

1. Konstanta a sebesar 3,224 menyatakan bahwa jika variabel $\mathrm{X} 1$, dan X2 konstan, maka variabel $\mathrm{Y}$ adalah 3,224.

2. Koefisien regresi $\mathrm{X} 1$ sebesar 0,272 menyatakan bahwa jika kualitas produk meningkat satu satuan, maka keputusan pembelian produk akan meningkat sebesar 0,116 dengan asumsi variabel bebas lain besarnya konstanta.

3. Koefisien regresi X2 sebesar 0,324 menyatakan bahwa jika kulitas layanan meningkat satu satuan, maka keputusan pembelian produk akan meningkat sebesar 0,121 dengan asumsi variabel bebas lain besarnya konstanta.

\section{Koefisien Determinasi}

Berdasarkan hasil penelitian dapat ditafsirkan bahwa pengaruh kualitas produk dan kualitas layanan terhadap keputusan pembelian produk sebesar 50,5\% atau dengan kata lain 50,5\% variasi nilai variabel keputusan pembelian produk dapat diterangkan oleh variabel kualitas produk dan kualitas layanan, sedangkan sisanya sebesar 49,5\% merupakan kontribusi atau pengaruh variabel lainnya yang tidak dimasukkan ke dalam model penelitian ini.

\section{Uji Statistik t}

Berdasarkan hasil otput pengolahan data maka didapat hasil sebagai berikut :

1. Nilai thitung untuk variabel profesionalisme auditor $\left(\mathrm{X}_{1}\right)$ lebih besar dari nilai $t_{\text {tabel }}$, yaitu 4,917 > 2,025. Dengan demikian $\mathrm{H}_{0}$ ditolak dan $\mathrm{H}_{\mathrm{a}}$ diterima. Sehingga dapat disimpulkan bahwa variabel kualitas produk secara parsial mempunyai pengaruh positif dan signifikan terhadap keputusan pembelian produk

2. Nilai thitung untuk variabel kualitas layanan (X2) lebih besar dari nilai ttabel, yaitu 2,675 > 2,025. Dengan demikian HO ditolak dan $\mathrm{Ha}$ diterima. Sehingga dapat disimpulkan bahwa variabel kualitas layanan secara parsial mempunyai pengaruh positif dan signifikan terhadap keputusan pembelian produk.

\section{Uji Statistik F}

Hasil analisis regresi yang menunjukkan nilai $\mathrm{F}_{\text {hitung }}=49,573$ sedangkan nilai $\mathrm{F}$ tabel pada $\alpha=0,05$ dan derajat bebas 2 dan $\mathrm{n}=84 \mathrm{df}=81$ adalah 3,109 Jadi $F_{\text {hitung }}=49,573>F$ tabel 3,109. Ini berarti bahwa $\mathrm{H}_{0}$ ditolak dan Ha diterima pada tingkat signifikansi $\alpha=0,05$.

Dengan demikian dapat disimpulkan bahwa kualitas produk dan kualitas layanan secara simultan berpengaruh secara signifikan terhadap keputusan pembelian produk.

\section{KESIMPULAN DAN SARAN \\ Kesimpulan}

Berdasarkan hasil penelitian yang telah dilakukan, maka dapat disimpulkan hal-hal sebagai berikut:

1. Hasil pengujian parsial pengaruh kualitas produk $\left(\mathrm{X}_{1}\right)$ terhadap keputusan pembelian produk diperoleh nilai $t_{\text {hitung }}$ lebih besar dari nilai $\mathrm{t}_{\text {tabel, }}$ yaitu $4,917>2,025$ maka $\mathrm{H}_{0}$ ditolak dan $\mathrm{H}_{\mathrm{a}}$ diterima. Sehingga dapat disimpulkan bahwa variabel kualitas produk secara parsial mempunyai pengaruh positif dan signifikan terhadap terhadap keputusan pembelian produk. Besarnya pengaruh kualitas produk terhadap keputusan pembelian produk sebesar $50,5 \%$, dan sisanya sebesar 49,5\% merupakan kontribusi atau 
pengaruh variabel lainnya yang tidak dimasukkan ke dalam model penelitian ini. Hal ini menunjukkan bahwa semakin baik kualitas produk yang dimiliki oleh PT. Bank Syariah Mandiri Cabang Bogor, maka semakin baik keputusan pembelian produk.

2. Hasil pengujian parsial pengaruh kualitas layanan $\left(\mathrm{X}_{2}\right)$ terhadap keputusan pembelian produk diperoleh nilai $t_{\text {hitung }}$ untuk lebih besar dari nilai $\mathrm{t}_{\text {tabel}}$, yaitu 2,675> 2,025 maka $\mathrm{H}_{0}$ ditolak dan $\mathrm{H}_{\mathrm{a}}$ diterima. Sehingga dapat disimpulkan bahwa variabel kualitas layanan mempunyai pengaruh positif dan signifikan terhadap keputusan pembelian produk. Besarnya pengaruh kualitas layanan terhadap keputusan pembelian produk sebesar 50,5\%, sisanya sebesar $49,5 \%$ merupakan kontribusi atau pengaruh variabel lainnya yang tidak dimasukkan ke dalam model penelitian ini. kualitas layanan berpengaruh positif dan signifikan terhadap keputusan pembelian produk. Hal ini menunjukkan bahwa semakin tinggi kualitas layanan yang dimiliki oleh PT. Bank Syariah Mandiri Cabang Bogor, maka semakin baik keputusan pembelian produk.

3. Hasil pengujian pengaruh simultan pengaruh kualitas produk $\left(\mathrm{X}_{1}\right)$ dan kualitas layanan $\left(\mathrm{X}_{2}\right)$ terhadap keputusan pembelian produk diperoleh $\mathrm{F}_{\text {hitung }}=37,499>\mathrm{F}_{\text {tabel }}$ 3,109 maka $\mathrm{H}_{0}$ ditolak dan $\mathrm{H}_{\mathrm{a}}$ diterima sehingga dapat disimpulkan pengaruh kualitas produk dan kualitas layanan secara simultan berpengaruh secara signifikan terhadap keputusan pembelian produk. Hal ini menunjukkan bahwa semakin baik kualitas produk dan kualitas layanan, maka semakin baik keputusan pembelian produk Tabungan BSM.

\section{Saran}

Dari kesimpulan diatas, maka penelitian mengajukan saran sebagai berikut:

1. Bagi Perusahaan

Hendaknya PT. Bank Syariah Mandiri mempertimbangkan pengembangan produknya secara berkala dan memberikan pelatihan kepada karyawan agar dapat memberikan pelayanan yang dapat memuaskan Nasabahnya.

2. Bagi peneliti selanjutnya
Para peneliti dapat menambah variabel independen yang diduga mempengaruhi keputusan pembelian produk, serta memperluas objek penelitian pada Bank selain PT. Bank Syariah Mandiri sehingga hasil penelitian lebih komprehensif.

\section{Referensi}

[1] Antonio, Muhammad Syafi'i.(2012). Bank Syariah, Dari

Teori ke Praktik. Gema Insani. Depok.

[2] Azwar, Saifuddin.(2016). Metode Penelitian. Penerbit

Pustaka Pelajar. Yogyakarta.

[3] Bank Indonesia, Surat Edaran No.10/14/DPbS (2008).

Pelaksanaan Prinsip Syariah Dalam Kegiatan Penghimpunan Dana dan Penyaluran Dana Serta Pelayanan Jasa Bank Syariah

[4] Bank Indonesia, Peraturan No.9/19/PBI/2007 (2007).

Pelaksanaan Prinsip Syariah Dalam Kegiatan Penghimpunan Dana dan Penyaluran Dana Serta Pelayanan Jasa Bank Syariah

[5] Bank Indonesia, Peraturan No.10/16/PBI/2008 (2008).

Perubahan Atas Peraturan Bank Indonesia Nomor 9/19/PBI/2007 Tentang Pelaksanaan Prinsip Syariah Dalam Kegiatan Penghimpunan Dana dan Penyaluran Dana Serta Pelayanan Jasa Bank Syariah

[6] Achmad K Permana, (Selasa, 19 September 2017) Banking Journalis Academy (BJA) 2017 di Jakarta. Berita Online : Suara.Com

[7] Darmawi, Herman. (2012). Manajemen Perbankan,

Penerbit Bumi Aksara, Jakarta.

[8] Endang Rosawati, (Jumat, 29 April 2016). Berita online :

Sindo News.Com

[9] Ginting, Nembah F. Hartimbul (2011). Manajemen

Pemasaran, Penerbit Yrama Widya, Bandung. 
[10] Kotler, Philip and Armstrong, Garry. (1996). Principle of marketing. $6^{\text {th }}$ edition. Prentice Hall, New Jersey.

[11] Kotler, Philip and Armstrong, Garry (2008). Prinsip-

Prinsip Pemasaran. Jilid 1. Penerbit Erlangga, Jakarta.

[12] Kotler, Philip and Keller, K. Lane. (2009). Manajemen

Pemasaran. Edisi 13 Jilid 1. Penerbit Erlangga, Jakarta.

[13] Kotler, Philip and Keller, K. Lane. (2009). Manajemen

Pemasaran. Edisi 13 Jilid 2. Penerbit Erlangga, Jakarta.

[14] Kotler, Philip and Keller, K. Lane. (2012). Marketing

Management, $14^{\text {th }}$ ed. Upper Saddle River,

NJ:Pearson

Education Inc.

[15] Nasehudin, Toto Syatori dan Gozali, Nanang.(2015).

Metode Penelitian Kuantitatif. Penerbit Pustaka Setia, Bandung.

[16] Oliver L, Richard. (1997). Satisfaction, A Behavioral

Perspective on the Customer. McGraw-Hill, companies in

Singapore

[17] Priyatno, Duwi. (2017). Panduan Praktis Olah Data

Menggunakan SPSS. Penerbit Andi. Yogyakarta.

[18] Perwataatmadja, Karnaen H \& Antonio, Muhammad

Syafi'i (1999). Apa \& Bagaimana Bank Islam. Dana Bhakti Prima Yasa, PT. Yogyakarta

[19] Republik Indonesia. (1998). Undang-Undang Republik Indonesia Nomor 10 Tahun 1998 Tentang Perubahan Atas

UU Nomor 7 Tahun 1992 Tentang Perbankan.

[20] Republik Indonesia. (2008). Undang-Undang Republik

Indonesia Nomor 21 Tahun 2008 Tentang Perbankan Syariah.
[21] Situs Otoritas Jasa Keuangan https;//ojk.go.id/statisticperbankan-syariah

[22] Sujarweni, V. Wiratna (2015). Metodologi Penelitian

Bisnis dan Ekonomi. Cetakan Pertama. Penerbit Pustaka Baru Press, Yogyakarta.

[23] Sugiyono. (2015). Metode Penelitian Bisnis. Cetakan

Kelima. Penerbit CV. Alfabeta. Bandung.

[24] Suryani, Tatik.(2017). Manajemen Pemasaran, Strategik

Bank di Era Global, Menciptakan Nilai Unggul Untuk Kepuasan Nasabah. Penerbit Prenadamedia Group, Jakarta.

[25] Tjiptono, Fandy. (2008). Strategi Pemasaran. Edisi 4.

Penerbit Andi. Yogyakarta

[26] Tjiptono, Fandy dan Chandra, Gregorius. (2016). Service,

Quality dan Satisfaction Edisi 4, Penerbit Andi, Yogyakarta.

[27] Tjiptono, Fandy dan Chandra, Gregorius. (2017). Pemasaran Strategik, Branding Strategy, Customer Satisfaction, Strategi Kompetitip hingga e-Marketing Edisi 3, Penerbit Andi, Yogyakarta.

[28] Tjiptono, Fandy. (2017). Service Management, Mewujudkan Layanan Prima. Edisi 3. Penerbit Andi. Yogyakarta

[29] Umam, Khotibul dan Budi Utomo, Setiawan (2017).

Perbankan Syariah, Dasar-dasar dan Dinamika Perkembangannya di Indonesia, Penerbit Raja Grafindo Persada, Jakarta

[30] Valarie A. Zeithaml dan Mary Jo Bitner (1996). Services Marketing, Mc Graw-Hill, International Edition.

[31] Website.www.syariahmandirico,id 